\title{
Spring recharge and groundwater flow patterns in flysch aquifer in the
}

\section{Połonina Wetlińska Massif in the Carpathian Mountains}

\author{
Karolina MOSTOWIK* (D) https://orcid.org/oooo-0003-2945-5909; ${ }^{\circledR}$ e-mail: karolina.mostowik@doctoral.uj.edu.pl \\ Damian KRZYCZMAN ${ }^{1}$ iD https://orcid.org/oooo-0001-6642-586X; e-mail: damian.krzyczman@gmail.com \\ Eliza PŁACZKOWSKA² iD https://orcid.org/oooo-0001-7993-6706; e-mail: eliza.placzkowska@zg.pan.krakow.pl \\ Bartłomiej RZONCA1 (iD https://orcid.org/oooo-0oo2-8938-1457; e-mail: b.rzonca@uj.edu.pl \\ Janusz SIWEK1 (iD https://orcid.org/oooo-ooo3-1636-1524; e-mail: janusz.siwek@uj.edu.pl \\ Patryk WACŁAWCZYK1 iD https://orcid.org/oooo-0003-3142-940o; e-mail: patryk.waclawczyk@doctoral.uj.edu.pl \\ ${ }^{*}$ Corresponding author \\ 1 Institute of Geography and Spatial Management, Jagiellonian University in Kraków, Gronostajowa St. 7, 30-387 \\ Kraków, Poland \\ 2 Institute of Geography and Spatial Organization, Polish Academy of Sciences, Św. Jana St. 22, 31-o18 Kraków, Poland
}

\begin{abstract}
Citation: Mostowik K, Krzyczman D, Płaczkowska E, et al. (2021) Spring recharge and groundwater flow patterns in flysch aquifer in the Polonina Wetlińska Massif in the Carpathian Mountains. Journal of Mountain Science 18(4). https://doi.org/10.1007/s11629-020-6524-2
\end{abstract}

(C) The Author(s) 2021.

\begin{abstract}
Flysch-type aquifers in the Eastern Carpathians usually feed periodic and low-discharge springs. However, in some areas, such as in the upper part of the Połonina Wetlinska Massif, perennial springs with a relatively high discharge were identified. Therefore, the aim of this study was to identify recharge and groundwater flow patterns of three high-discharge springs based on the response of spring discharge to rainfall and on the relationship between specific electrical conductivity of water and spring discharge. The relation between spring discharge and rainfall was investigated by crosscorrelation analyses. Generally, cumulative rainfall over a period from 10 days to 3 months is most strongly correlated with discharge; however, the response time of spring discharge varies throughout the year. Faster response to rainfall occurs in the spring after snowmelt, while in the summer and
\end{abstract}

Received: 13 -Oct-2020

Revised: 02-Feb-2021

Accepted: $19-\mathrm{Feb}-2021$ autumn months the response time increases. Two flow systems were identified: 1) a relatively deep, fissure-pore flow system with a long response time to precipitation and 2) a shallow, fissure-dominated system with a short response time, which is superimposed on the longer response. A small range of specific electrical conductivity combined with the varying discharge of two springs suggests that dilution of groundwater by rainwater does not play a significant role. The differences in the studied springs' response to rainfall can be attributed to the recharge area, regolith features and local bedrock structures, i.e. occurrence of joints and faults, monoclinal dip of rock layers and gravitational slope deformations including ridge-top trenches, which, thus far, have been underestimated in determining groundwater storage capacity in the flysch part of the Carpathians.

Keywords: Cross-correlation; Rainfall recharge; Spring response; Sedimentary rocks; Poland 


\section{Introduction}

Determining the parameters of aquifers by interpreting spring discharge is one of the oldest methods used in hydrogeology, developed intensively since as early as the $19^{\text {th }}$ century (Maillet 1905; Bonacci 1987). Springs recharged by groundwater penetrating within a shallow active zone are generally characterized by quick response time, even to single rainfall events. In turn, long spring response time is characteristic of springs draining deep aquifers and distant recharge areas. Inferring about groundwater storage capacity based on the dynamics of the groundwater depletion process, including the mechanism of recession of a spring recharged by studied aquifer, is indirect and is based on the simple assumption that the greater the groundwater storage capacity, the more slowly its resources are depleted, which manifests itself in a more stable and longlasting recharge of springs (e.g. Maillet 1905; Kovács et al. 2005; Buczyński and Rzonca 2011; Płaczkowska et al. 2018). In addition to assessing the rate of depletion of aquifer resources during dry periods, the dynamics of spring discharge after periods of recharging the catchment with rainfall are also interpreted. This makes it possible to draw conclusions about the time of water residence in aquifers and the recharge pattern, in particular the rate of groundwater flow and pressure transfer (Bonacci 1987; Halihan and Wicks 1998; Lee and Lee 2000; Kovács et al. 2005; Fiorillo and Doglioni 2010; Diodato et al. 2014). The main difficulty in interpretation is the fact that the increased spring discharge following the rainfall does not necessarily result from the simple mechanism of inflow of fresh water, but usually from a general pressure increase in the aquifer and the release of "old" stored water pushed out by the "new" water infiltrated from the surface (Maloszewski et al. 2002). The mechanisms of groundwater flow and its gravity drainage from the aquifer are complicated (also in terms of mathematical description) and constitute various modifications and combinations of conceptual models, e.g. the piston flow model and exponential flow model, which are additionally modified by a number of physical phenomena such as mixing of waters of varying properties, molecular diffusion and preferential flow, and others observed in reservoirs of double or triple porosities (Maloszewski et al. 2002; 2004; Sukhija et al. 2003; Maloszewski 2004; Kovács and Perrochet 2008; Zuber et al. 2008).

Springs in the Outer Carpathians, built of flysch rocks, drain shallow aquifers supplied with rain and snowmelt water. In recent years, this pattern has overlapped with pronounced climate warming, especially a gradual decrease in snow depth and snow-to-precipitation ratio in the winter, increased evapotranspiration in the summer, a decrease in the contribution of summer rainfall to the annual total, as well as longer periods without rain (Mostowik et al. 2019b; Pińskwar et al. 2019; Szwed 2019). In addition, owing to the complexity of snow cover forming and melting processes in mountain areas, their spatial variability, and the lack of monitoring these changes (such as snow water equivalent), the relationship between spring discharge and snow melting conditions is difficult to clearly identify and describe (Humnicki 2013). The generally complicated patterns of aquifer recharge and drainage cause the displacement and overlapping of water volumes from particular seasons and the inflow of water from recent infiltration, which affect spring discharge.

Aquifers in the Flysch Carpathians pose particular difficulties to detailed hydrogeological characterization, especially in terms of identifying groundwater resources and recharge patterns. Aquifers are strongly heterogeneous and anisotropic because they are made of alternating layers of fractured sandstones, characterized by low porosity and permeability of a rock matrix, and clay- or mudstone ductile shale that constitutes aquitards. In addition, these rocks occur in the conditions of very strong tectonic overprint. It has always been emphasized that despite the presence of numerous springs in the Flysch Carpathians, most of them are characterized by low discharge (Chełmicki et al. 2011; Bartnik and Moniewski 2019) and recharged from thin, superficial permeable zone. Thus, deeper groundwater recharge has been marginalized; it has been believed not to play a significant role. Therefore, the identification of springs of discharge periodically exceeding $40 \mathrm{dm}^{3} \cdot \mathrm{s}^{-1}$ in the Polonina Wetlińska Massif (the High Bieszczady Mountains, Polish Flysch Carpathians) was a significant change. On the one hand, it shed completely new light on the mechanisms of groundwater flow patterns in flysch rocks (Mocior et al. 2015; Mostowik et al. 2016; Płaczkowska et al. 2018). On the other hand, it provided the opportunity to carry out more detailed research based on the interpretation of hydrographs of these springs, 
currently treated as valuable observation sites.

The objective of this work is to identify the recharge and groundwater flow patterns in aquifers represented by flysch rocks, based on the response time of spring discharge to rainfall recharge and selected physical properties of water. Within this main objective, three issues will be addressed: (i) the relationship between rainfall and spring discharge; (ii) the relationship between spring discharge and the specific electrical conductivity of water (SEC); and (iii) factors determining observed differences in the response of springs to recharge impulses.

\section{Material and Methods}

\subsection{Study area}

The Połonina Wetlińska Massif $\left(49.17^{\circ} \mathrm{N}, 22.52^{\circ} \mathrm{E}\right)$ in the Bieszczady Mountains, which is the study area (Fig. 1), is built of flysch rocks belonging to the Silesian Unit (Malata et al. 2006). These mainly consist of thick-bedded Otryt sandstone interlayered with less resistant shale and thin-bedded sandstone the total thickness of this member is up to $2000 \mathrm{~m}$ (Fig. 1). According to Chowaniec et al. (1983) and Machowski (2010), these rocks are characterized by low storage capacity, caused by quite low porosity (usually less that $6 \%$ ) and low hydraulic conductivity $\left(1.4 \times 10^{-6} \mathrm{~m} \cdot \mathrm{s}^{-1}\right.$ to a depth of $20 \mathrm{~m}$ and $2.4 \times 10^{-7} \mathrm{~m} \cdot \mathrm{s}^{-1}$ in the depth range of $20-40 \mathrm{~m}$ ), as well as by the shallowness of the permeable zone, up to a maximum of 100 metres. The water flow in aquifers occurs mainly via fissure- or fissure-pore systems. The steep slopes and low retention capacity of the bedrock combined with a dense drainage network limit recharge and groundwater storage as well as promote rapid surface runoff (Płaczkowska et al. 2015). These characteristics are reflected in the rate of groundwater component in the overall river flow, which is generally low in the Bieszczady Mountains and varies in different catchments from $25 \%$ to $45 \%$ (Lajczak 1996). Aquifers in the Flysch Carpathians are drained by numerous springs of small discharge, usually $<0.5$ $\mathrm{dm}^{3} \cdot \mathrm{s}^{-1}$ (Chełmicki et al. 2011).

On the other hand, fractures of tectonic origin occurring in the ridge zones strongly increase the permeability and depth of the active zone in specific localities, thus enlarging the bedrock retention capacity (Kleczkowski 1979; Machowski 2010;
Mostowik et al. 2018). In addition, the subsurface water flow in the Połonina Wetlińska slopes is locally modified as a result of mass movements (e.g. lateral spreading, landslide, rock flow), solifluction, and mechanical weathering (Haczewski et al. 2007). The soil thickness is low and depends on the slope, from over $1 \mathrm{~m}$ on flat slopes $\left(0^{\circ}-6^{\circ}\right)$, to $0.5^{-0.3 \mathrm{~m} \text { on }}$ slopes $>15^{\circ}$, and on the ridge (Kacprzak 2001). The regolith usually does not exceed $3 \mathrm{~m}$ (Kukulak 2001), however due to local mass movements it may increase several times.

Aquifers are recharged by direct infiltration from the surface. The annual precipitation totals in the study area range from $900 \mathrm{~mm}$ in valleys to a probable maximum of 1,600-1,700 $\mathrm{mm}$ on hilltops (Laszczak et al. 2011; Mostowik et al. 2019b). Another factor also related to altitude is snow cover duration, which in valleys lasts 60-70 days in winter months (Szwed et al. 2017). This period increases with altitude, which means that in the highest parts of the mountains the first snow (not forming a permanent cover) can be expected in November and that the snow cover will have disappeared in April. The landscape of the Bieszczady Mountains is seminatural. It is dominated by beech and fir forests up to an altitude of 1,150 $\mathrm{m}$ a.s.l. and subalpine and alpine meadows covering the highest ridges. The research area covers the ridge zone of the Połonina Wetlińska Massif.

\subsection{Characteristics of the studied springs}

The studied springs are located at altitudes ranging from 948 to $1,079 \mathrm{~m}$ a.s.l., on the northern slope of the Połonina Wetlinska, one of the mountain ranges in the Bieszczady Mountains rising to a maximum of $1,255 \mathrm{~m}$ a.s.l. (Fig. 1). The studied springs are hillslope springs, above which there are channel heads with well-developed niches (No. 3 and No. 7) or sections of dry V-shaped valleys - No. 5 . Despite their location close to the ridge line and the small areas of topographic catchments (from 0.04 to $0.38 \mathrm{~km}^{2}$ ), the springs under investigation are characterized by relatively high discharge rates for springs draining a flysch bedrock and they flow almost continuously (Mocior et al. 2015; Mostowik et al. 2016; Płaczkowska et al. 2018). Average spring discharges ranged from 3.3 to $9.6 \mathrm{dm}^{3} \cdot \mathrm{s}^{-1}$ in the period 2013-2016, while averages in individual years showed significant differences (Fig. 2, Table 1), depending on 


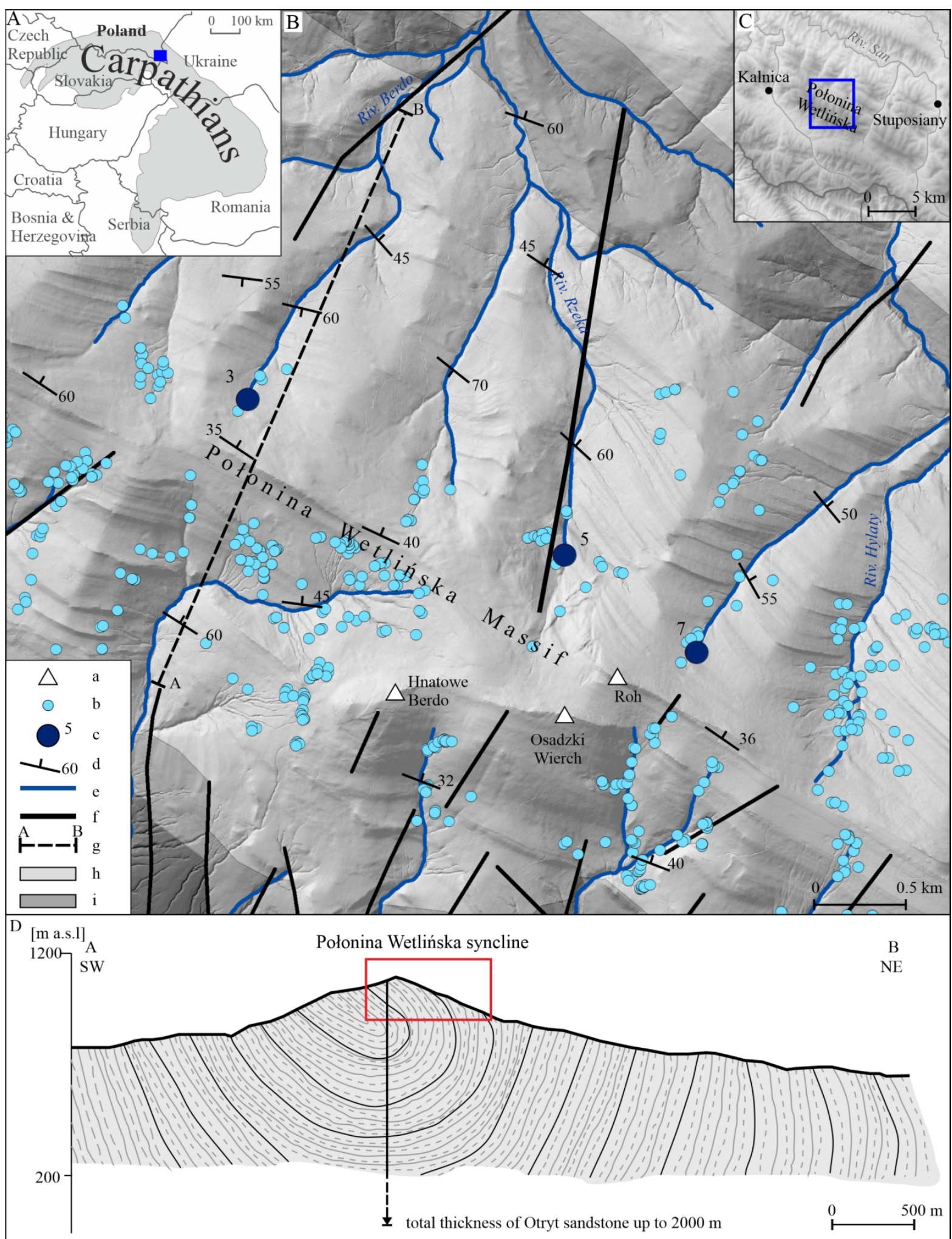

Fig. 1 (A) The study area in the Carpathian Mountains; (B) the Polonina Wetlińska Massif with its geological and tectonic background (source: Malata et al. 2006; Haczewski et al. 2007), a - peaks, b - springs mapped in the zone above $900 \mathrm{~m}$ a.s.l. (after Mocior et al. 2015), c - numbered studied springs (numbering of springs according to Płaczkowska et al. 2018), d - strike and dip, e - streams, $\mathrm{f}$ - faults, $\mathrm{g}$ - line of cross section, $\mathrm{h}$ - sandstone-shale member, i - shale-sandstone member; (C) the weather stations' location (black dots); (D) Geologic cross section through the Połonina Wetlińska, red rectangle shows the extent of conceptual models on Fig. 6. 

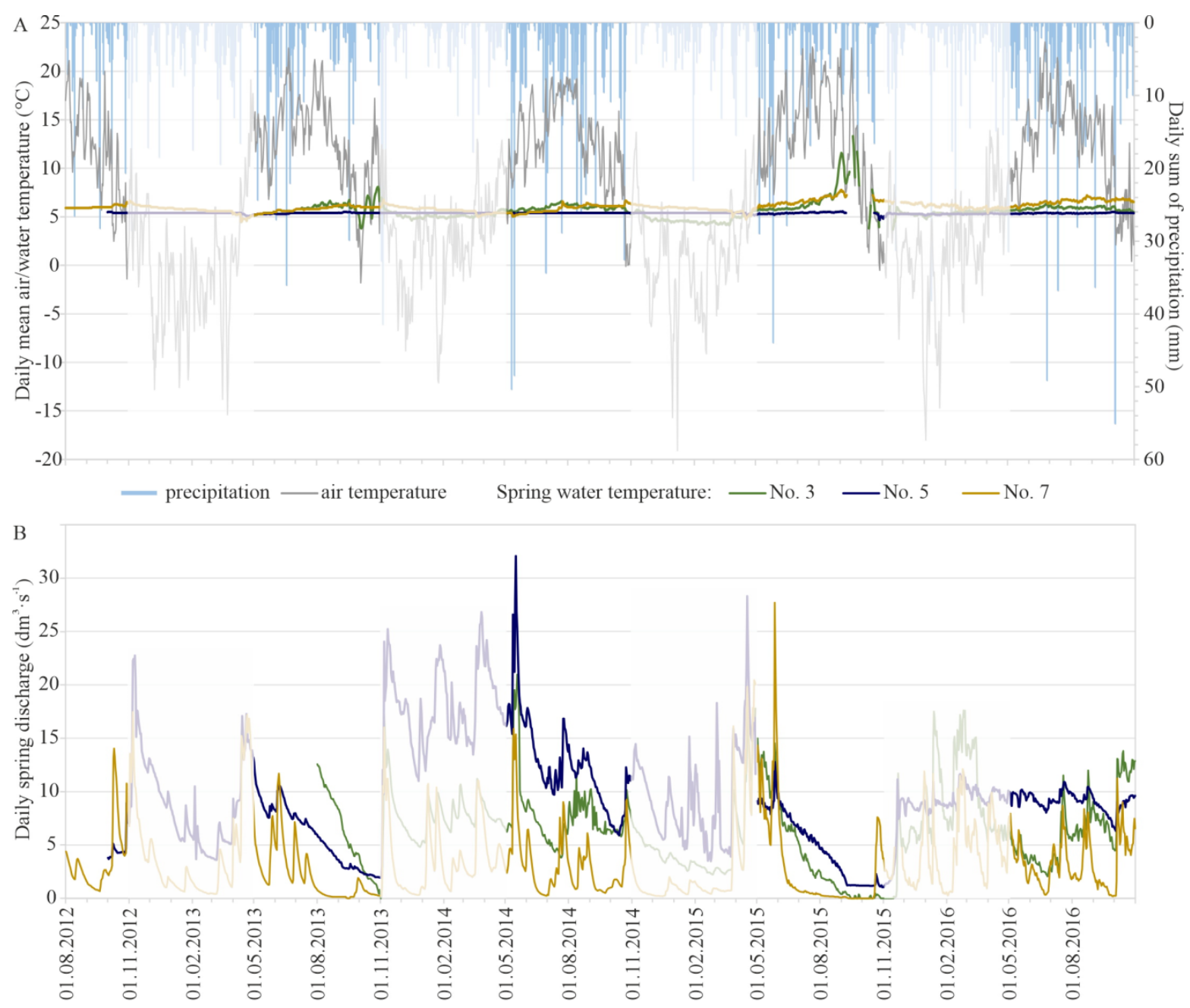

Fig. 2 (A) Daily mean air temperature, precipitation sum (Stuposiany weather station) and spring water temperature; (B) daily mean spring discharge during the study period. The cold half-year (not analyzed) is shaded.

Table 1 Average annual (Nov-Oct) discharge of the studied springs in relation to precipitation totals

\begin{tabular}{|l|l|l|l|l|l|l|}
\hline Spring No. & Monitored period & \multicolumn{7}{|l|}{ Average } & annual discharge $\left(\mathrm{dm}^{3 \cdot} \cdot \mathrm{s}^{-1}\right)$ & 2016 & $2013-2016$ \\
\hline 3 & 2013 & 2014 & 2015 & 7.3 & 6.5 \\
\hline 5 & Aug 2013-Oct 2016 & nd & 7.8 & 4.5 & 8.8 & 9.6 \\
\hline 7 & Oct 2012-Oct 2016 & 7.4 & 15.2 & 7.2 & 3.8 & 3.3 \\
\hline Rain gauge & Aug 2012-Oct 2016 & 3.2 & 3.5 & 2.8 & $7 \%)$ \\
\hline Stuposiany & & Ratio of annual precipitation totals to average precipitation totals (\%) & 102 & 91 \\
\hline Kalnica & & 83 & 102 & 77 & 101 & 88 \\
\hline
\end{tabular}

Note: nd means lack of complete annual data.

precipitation form, intensity and totals. Throughout the year, the highest discharges of groundwater usually occur in spring (Fig. 2), which is related to the snowmelt recharge of aquifers and, additionally, to rainfall. In turn, the minimum discharge falls in the autumn and winter months. Spring discharge is highly variable, while the temperature of spring waters fluctuates only slightly. The average annual temperature of spring waters in the examined period (Fig. 2, Table 2) was $5.4^{\circ} \mathrm{C}$ (spring No. 5), $5.7^{\circ} \mathrm{C}(\mathrm{No} .3$ ) and $6.0^{\circ} \mathrm{C}$ (No. 7). Based on the previous studies water temperature was almost constant in spring No. $5\left( \pm 0.1^{\circ} \mathrm{C}\right)$ throughout the year, while in others there were seasonal fluctuations by approx. $\pm 1.0^{\circ} \mathrm{C}$; there was no significant relation between water temperature and spring discharge (Kisiel et al. 2015; 
Table 2 Spring water temperature in the studied period

\begin{tabular}{|c|c|c|c|c|c|c|c|c|c|c|c|c|}
\hline \multirow{3}{*}{$\begin{array}{l}\text { Spring } \\
\text { No. }\end{array}$} & \multicolumn{12}{|c|}{ Water temperature $\left({ }^{\circ} \mathrm{C}\right)$} \\
\hline & \multicolumn{3}{|l|}{2013} & \multicolumn{3}{|l|}{2014} & \multicolumn{3}{|c|}{2015} & \multicolumn{3}{|l|}{2016} \\
\hline & mean & $\min$ & $\max$ & mean & $\min$ & $\max$ & mean & $\min$ & $\max$ & mean & $\min$ & $\max$ \\
\hline 3 & nd & nd & nd & 5.6 & 4.6 & 7.0 & 5.7 & 3.8 & 13.3 & 5.6 & 3.7 & 6.3 \\
\hline 5 & $5 \cdot 4$ & 5.1 & $5 \cdot 5$ & 5.4 & $5 \cdot 3$ & 5.4 & 5.4 & 4.7 & 5.6 & $5 \cdot 3$ & 4.8 & 5.5 \\
\hline 7 & 5.8 & 4.5 & 6.7 & 5.8 & 5.0 & 6.7 & 6.2 & 4.7 & 7.8 & 6.3 & $5 \cdot 4$ & 7.2 \\
\hline
\end{tabular}

Note: nd means lack of data.

Płaczkowska et al. 2018). The lowest water temperature occurred in winter in spring No. 3 and in March and April in spring No. 7 (Fig. 2), whereas the highest water temperature was noted from July to October in both springs. The average air temperature in the period 2013-2016 (Stuposiany station) was $6.8^{\circ} \mathrm{C}$ and varied from $-3.0^{\circ} \mathrm{C}$ in January to $16.9^{\circ} \mathrm{C}$ in July. The average air temperature in the upper part of the Połonina Wetlińska Massif is expected to be about $2^{\circ} \mathrm{C}$ lower than in Stuposiany.

\subsection{Methods}

This study is based on data covering the daily discharge of three springs located on the northern slope of the Połonina Wetlińska Massif (Fig. 1), recorded in the years 2012-2016 (Fig. 2, Table 1). The measurements were performed using the Keller DCX22AA water level (error 0.05\% FS) and temperature logger. The springs' discharge rates for the entire observation period were calculated on the basis of the logged water level data and the rating curves. Data recording took place using an hourly time step and then were averaged to daily discharge. In addition, the specific electrical conductivity (SEC) of spring water was measured periodically using the Elmetron CPC401 conductivity meter. The coefficient of quartile deviation $\left(c_{v}\right)$ was calculated based on SEC measurements as follows:

$$
c_{v}=\left(\mathrm{SEC}_{75 \%}-\mathrm{SEC}_{25 \%}\right) /\left(\mathrm{SEC}_{75 \%}+\mathrm{SEC}_{25 \%}\right)
$$

Meteorological data included daily precipitation totals from the period of 2012-2016 recorded at the nearest stations in Kalnica (6 km west, $576 \mathrm{~m}$ a.s.l.) and Stuposiany (11 km east, $547 \mathrm{~m}$ a.s.l.), which are part of the national meteorological monitoring network (Table 1). Despite the fact, that stations are located at lower altitude than studied springs, they may be considered as quite well representing local weather conditions. Using data from both stations enabled to avoid random results based only on one rain gauge. Precipitation gradient in the Polonina Wetlińska is uncertain but precipitation totals in the ridge zone may be estimated up to $20 \%-30 \%$ higher than that in stations included in the study (Laszczak et al. 2011).

To determine the relationship between rainfall recharge and spring discharge, the cross-correlation analysis was used (Padilla and Pulido-Bosch 1995; Leszkiewicz and Różkowski 2000; Lee et al. 2006; Fiorillo et al. 2007; Jemcov 2007; Zhang et al. 2013; Diodato et al. 2014). According to the previous study (Płaczkowska et al. 2018), the springs may be identified as perennial with quite high groundwater storage capacity, which might result in a lack of an immediate increase in spring discharge after a rainfall event. Therefore, in addition to cross-correlations between daily discharge and daily rainfall, cumulative rainfall time series of different duration (1 to 100 days) with a time lag from o to 50 days were introduced to provide more detailed analysis of rainfall recharge influence on spring discharge and to comprehend a broader problem of groundwater flow patterns. The cross-correlation coefficient $\left(r_{x y}\right)$ was determined using the formula below:

$$
r_{x y}(k)=C_{x y}(k) /\left(\sigma_{x} \cdot \sigma_{y}\right)
$$

where $C_{x y}(k)$ is the covariance between time series $x$ (cumulative rainfall) and time series $y$ (daily spring discharge), computed at time lag $k, \sigma_{x}$ and $\sigma_{y}$ are the standard deviations of the time series. The level of significance assumed in all analyses in this study was $p \leq 0.05$.

Owing to the specific role played by snowmelt in groundwater recharge and the lack of sufficiently detailed data on snow cover duration, depth and water equivalent, data on winter spring discharge was excluded from the correlation analysis. This study only took into account daily discharge from the warm half-year period (May-Oct) and daily precipitation totals for the whole period. It has to be noticed that the data with longer lags (especially at the beginning of the warm half-year period) might have been influenced by March and April snowmelt and snowfall inputs which limits the inference about the relations between rainfall and spring discharge. Cross- 
correlation analyses were performed for the entire period (May-Oct) separately for cumulative rainfall from Kalnica and Stuposiany stations. Additionally, using rainfall data from the nearest station in Kalnica, cross-correlation analyses were done for individual months (May, June, July, August, September, October) in order to more accurately characterize the response of springs to rainfall during the half-year.

\section{Results}

\subsection{Warm half-year cross-correlations}

Correlograms were used to present the correlation coefficient between daily spring discharge and the cumulative rainfall, lasting for different periods as well as with different time lags. The crosscorrelation analysis revealed that for both rainfall cumulative series (Kalnica and Stuposiany) similar correlation coefficients were obtained for each spring discharge, which confirmed substantial differences between springs' responses (Fig. 3). Although the studied springs are situated within ca. $3 \mathrm{~km}$, their responses to rainfall recharge were clearly different. The discharge of springs No. 3 and No. 5, displayed a weak correlation with the rainfall from several preceding days, whereas the discharge of spring No. 7 was highly correlated with shorter periods of cumulative rainfall.
The discharge of Spring No. 3 during the warm half-year was most strongly correlated with the cumulative rainfall from a period of ca. 60 days immediately preceding this discharge $\left(r_{\text {Kalnica }}=0.41\right.$, $\left.r_{\text {Stuposiany }}=0.36\right)$. However, $r>0.3$ was obtained for a wide interval of rainfall accumulation (20 to 100 days). The rate of decrease in the correlation coefficient with the increase in time lag for spring No. 3 was the smallest among the three analysed springs (Fig. 3). The highest values of the correlation coefficient $\left(r_{\text {Kalnica }}=r_{\text {Stuposiany }}=0.59\right)$ occurred in spring No. 5, which has the highest discharge, and the cumulative rainfall from the 40 days immediately preceding the correlated discharge. A generally high correlation ( $r>0.50)$ was also found for the cumulative rainfall in a range of 20-60 days. Spring No. 7 clearly differed from the first two springs in terms of lower discharge and shorter periods of cumulative rainfall for which the correlation coefficients were high. The strongest correlation between rainfall and the discharge of spring No. 7 occurred for a rainfall cumulative period of about 10 days, and 1 day lag $\left(r_{\text {Kalnica }}=r_{\text {Stuposiany }}=0.54\right)$. The rainfall totals from both shorter ( $<5$ days) and longer ( $>20$ days) periods were less strongly correlated with the discharge of spring No. 7. However, due to relatively similar correlation coefficients obtained for different cumulative rainfall periods, more detailed interpretation will be based on monthly crosscorrelations.

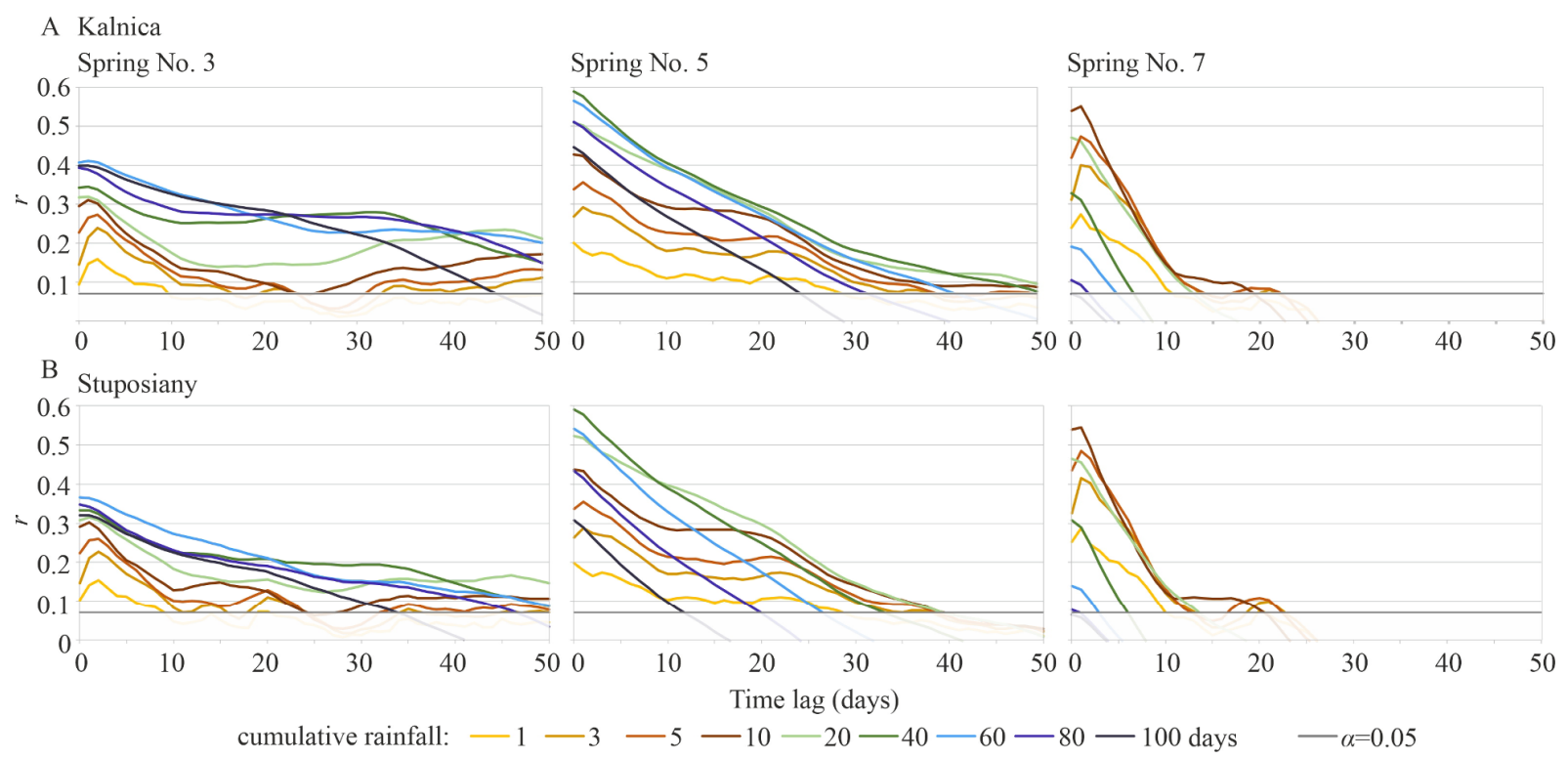

Fig. 3 Cross-correlation between cumulative rainfall (A - Kalnica, B - Stuposiany) and daily spring discharge for the warm half-year (May-Oct). 


\subsection{Monthly cross-correlations}

More detailed information regarding the recharge pattern of springs was obtained from the cross-correlation analysis for individual months. Undoubtedly, the specific relationships between cumulative rainfall and spring discharge differed in the analysed months, with the highest correlation coefficients for short lags (Fig. 4). In May, the discharge of spring No. 3 was strongly correlated $(r \approx 0.6)$ with rainfall totals from 5 to 10 days with a slight lag. In the case of spring No. 5 the maximum correlation $(r \approx 0.6)$ occurred for the rainfall of varying duration (e.g. 10, 20, 100 days) preceding the discharge on a given day. The discharge of spring No. 7 had the highest correlation coefficients for

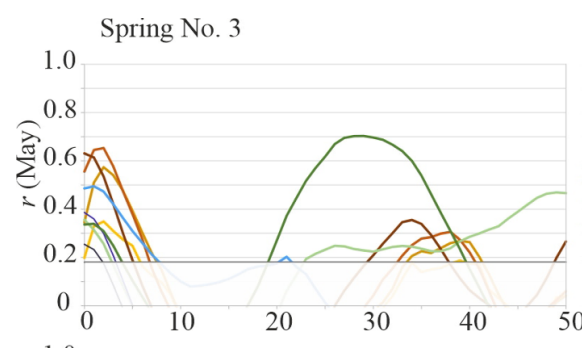

Spring No. 5

Spring No. 7
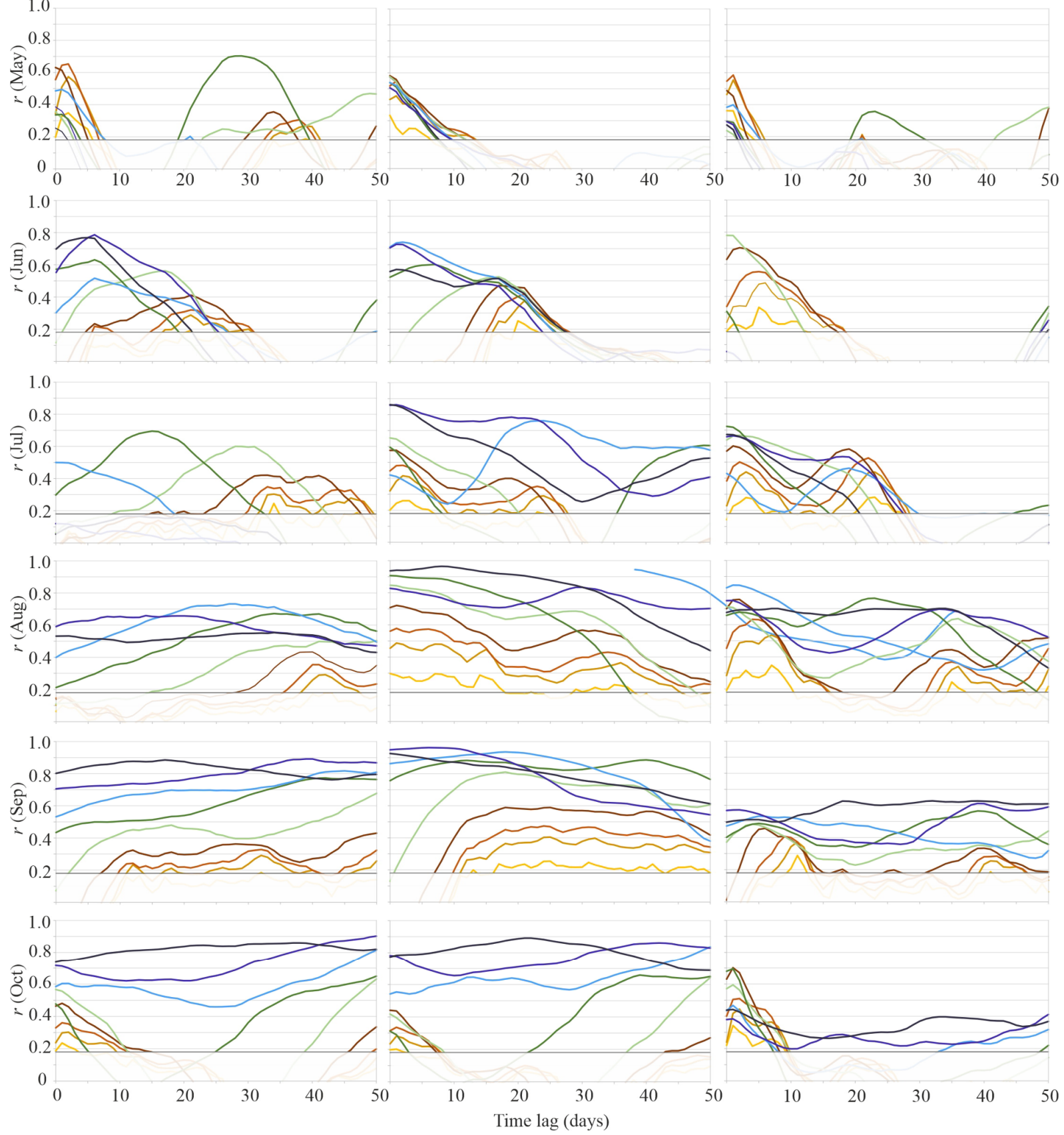

cumulative rainfall: $-1-3-5-10-20-40-60-80-100$ days $-\alpha=0.05$

Fig. 4 Cross-correlation between cumulative rainfall (Kalnica) and daily spring discharge analysed separately in months. 
cumulative rainfall from $3(r=0.55)$ and $5(r=0.58)$ days with a 1 day lag (Fig. 4). Furthermore, in May, the impact of rainfall from longer periods $(20-40$ days) with a lag of 1-2 months was clearly visible in springs No. 3 and 7.

In June, individual characteristics in the recharge of each spring became apparent. In the case of spring No. 3 , the strongest correlations $\quad(0.63<r<0.79)$ occurred for cumulative rainfall over a long period (40-100 days) with a few days lag. In spring No. 5, correlation coefficients were higher for longer periods of cumulative rainfall than in May - the strongest correlation $(r \approx 0.7)$ occurred for cumulative rainfall from $60-80$ days with a slight lag. In the case of spring No. 7 , the strongest correlation $(r=0.78)$ was observed for rainfall from 20 days preceding the discharge on a given day (Fig. 4).

The higher values of the correlation coefficient of the spring discharge in July noted for longer periods of rainfall totals indicate an increase in the significance of overall long-term meteorological conditions and a limited role of individual rainfall events. In the case of spring No. 3, the strongest correlations in July $(r \approx 0.7)$ occurred for cumulative rainfall from 40 days with a lag of 15 days. The rainfall totals from 80-100 days preceding the discharge on a given day $(0.80<r<0.90)$, and the rainfall total from 60 days with a lag of ca. 25 days $(r=0.76)$ were found to be strongly correlated with the discharge of spring No. 5. In spring No. 7 , there was a strong correlation

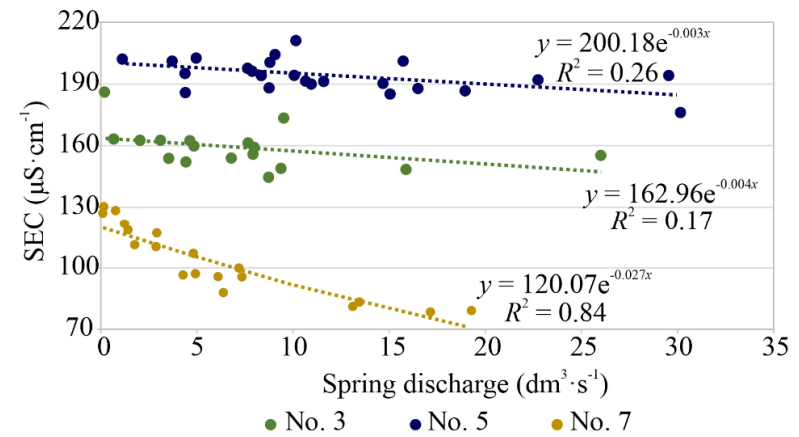

Fig. 5 Relationships between specific electrical conductivity (SEC) and spring discharge.

Table 3 Specific electrical conductivity (SEC) statistics based on periodic measurements

$\begin{array}{llll}\text { Parameter } & \text { Spring No. } 3 & \text { Spring No. } 5 & \text { Spring No. } 7 \\ \text { median } & 158.7 & 194.0 & 99.8 \\ \text { minimum } & 144.2 & 176.0 & 78.3 \\ \text { maximum } & 185.6 & 211.0 & 130.2 \\ c_{v} & 0.03 & 0.03 & 0.12\end{array}$

for the rainfall total from 40 days preceding the discharge on a given day $(r=0.72)$ but similar coefficients were also obtained for the cumulative period 20-100 days.

From August to October, the study registered a long cumulative rainfall period with a high correlation coefficient (Fig. 4). With cumulative rainfall periods $>40$ days in September and October, the correlation coefficient maintained a similar value regardless of the length of the lag. This suggests that spring discharge in late summer and autumn is strongly dependent on rainfall conditions in the preceding few months. In spring No. 7, in October, the strongest correlation $(0.59<r<0.69)$ was noted for shorter cumulative periods from 10 to 40 days with a slight lag.

\subsection{Specific electrical conductivity vs. spring discharge}

The relationship between the discharge of the analysed springs and their specific electrical conductivity clearly differed between spring No. 7 and springs No. 3 and 5 (Fig. 5, Table 3). The coefficients of SEC quartile deviation for the studied springs were $c_{v 3}=0.03, c_{v 5}=0.03$, and $c_{v 7}=0.12$ and suggested low SEC variability (Table 3). There is no clear SEC dependency of springs No. 3 and 5 on the discharge of these springs, i.e. the wide range of discharge variability was accompanied by a much smaller range of SEC variability (Fig. 5). However, in the case of spring No. 7, the relationship between discharge and SEC was evident, which testifies a clear groundwater dilution process with increasing discharge (Fig. 5).

\section{Discussion}

The evaluation of the spring discharge response to rainfall presented in the paper is a new approach in the study of the spring recharge pattern of the flysch part of the Carpathians. In southern Poland, research into the discharge response to rainfall or snowmelt has so far been carried out in karst aquifers (Leszkiewicz and Różkowski 2000; Dobek 2007; Humnicki 2013); in Europe, this method is widely used for springs in areas built of calcareous rocks (Bonacci 1987; Padilla and Pulido-Bosch 1995; Lee et al. 2006; Jemcov 2007; Fiorillo and Doglioni 2010). In mountainous flysch areas, perennial springs with discharge of several litres per second can constitute a 
significant part of the river runoff and are an important source of water supply for the population, therefore, an analysis of their dependence on precipitation and potential changes in the discharge regime is truly fundamental (Diodato et al. 2014).

The response of spring discharge to rainfall determined in this paper corresponds well with the results of Płaczkowska et al. (2018) on the depletion patterns of water resources and on the storage capacity of groundwater reservoirs feeding the springs. The average water residence time in the waterbearing system, calculated as the inverse of the recession coefficient of the springs No. 3, No. 5 and No. 7 , is, respectively, $T_{3}=47$ days, $T_{5}=50$ days, and $T_{7}=13$ days, and the groundwater renewal period is $R_{3}=53$ days, $R_{5}=59$ days, and $R_{7}=18$ days (Płaczkowska et al. 2018). The parameters mentioned above are approximately in line with the periods of cumulative rainfall, for which the correlation coefficients between the discharge and the rainfall total are highest, i.e. from 40 to 80 days in springs No. 3 and 5, and 10 days in spring No. 7. A similar spring discharge response (1-4 months) to rainfall was obtained for the Caraventa slope spring in the southern Apennines, which also drains a reservoir in fractured flysch rocks (Diodato et al. 2014).

According to Płaczkowska et al. (2018) there are two types of spring recharge. The first type is associated with shallow subsurface flow and faster supply of newly infiltrated water, which is the most common way of recharging in the flysch of the Outer Carpathians. In most cases, springs draining this way are characterized by low discharge $<0.5 \mathrm{dm}^{3} \cdot \mathrm{s}^{-1}$ (Chełmicki et al. 2011). In the studied area, this type of shallow subsurface flow pattern is represented by numerous descending, low discharge springs (spring density up to 48 per square kilometre, Mocior et al. 2015) including spring No. 7; however, its average discharge rate is much higher than typical -3.3 $\mathrm{dm}^{3} \cdot \mathrm{s}^{-1}$ (Fig. 6A). The other drainage mechanism is active in higher discharge springs No. 3 (Fig. 6B) and 5 (Fig. 6C), which are interpreted as overflow or contact springs. These springs drain a more extensive groundwater reservoir with longer water residencetime (Płaczkowska et al. 2018). Similar patterns of spring response to rainfall have been described for fractured meta-sediments in the Western Himalayan Mountains. Springs draining fractured quartzite were characterized by a longer response time, lower discharge variability, and a slower depletion rate than springs draining the hillslope colluvium (Negi and Joshi 2004).

Based on the cross-correlation analysis and previous research of Płaczkowska et al. (2018) two models of the flow system may be proposed: 1) a relatively deep flow system with a long response time to precipitation and 2) a shallow system with a short response time to precipitation, which is superimposed on the longer response throughout the year. Furthermore, the contribution of the deep and shallow components depends on the individual spring, time of the year and actual weather conditions. Almost constant water temperature in spring No. 5 (close to mean annual air temperature) and small seasonal variability of water temperature in springs No. 3 and 7 are clear indicator of a significant role of the dominant deep flow system which enable temperature stabilising, which is concise with results of other studies (Kisiel et al. 2015; Płaczkowska et al. 2018).

The two proposed models of the flow system may be linked to fissure and pore medium, through which groundwater flows. In the Połonina Wetlińska a complex fissure-pore system was suggested, whereas usually for the flysch aquifers in the Carpathians the predominance of fissure type was attributed (Chowaniec et al. 1983; Chełmicki et al. 2011; Płaczkowska et al. 2018). Moreover, spring response to rainfall and a type of groundwater flow system are supposed to be strongly related to the recharge area. In consequence, the deep flow in a complex fissurepore system yielding slow spring response may be related to a larger recharge area, definitely exceeding topographic water divide, as observed in springs No. 3 \& 5 (Fig. 6B, Fig. 6C). Spring No. 7 is recharged from a shallow, fissure-dominated system with limited recharge area, and therefore, demonstrates quite fast response to rainfall recharge. Similarly, local greater groundwater resources due to capacious fissure-pore system were suggested in few other fractured thickbedded sandstone formations in the Carpathians, however no continuous spring discharge measurements were undertaken (Buczyński et al. 2007; Łajczak 2016).

A detailed analysis of spring responses to rainfall in individual months indicates differences in response patterns throughout the year, related to the degree of saturation of aquifers. In the spring months, the quick spring response is clearly visible as resulting from maximum saturation of groundwater reservoirs after 


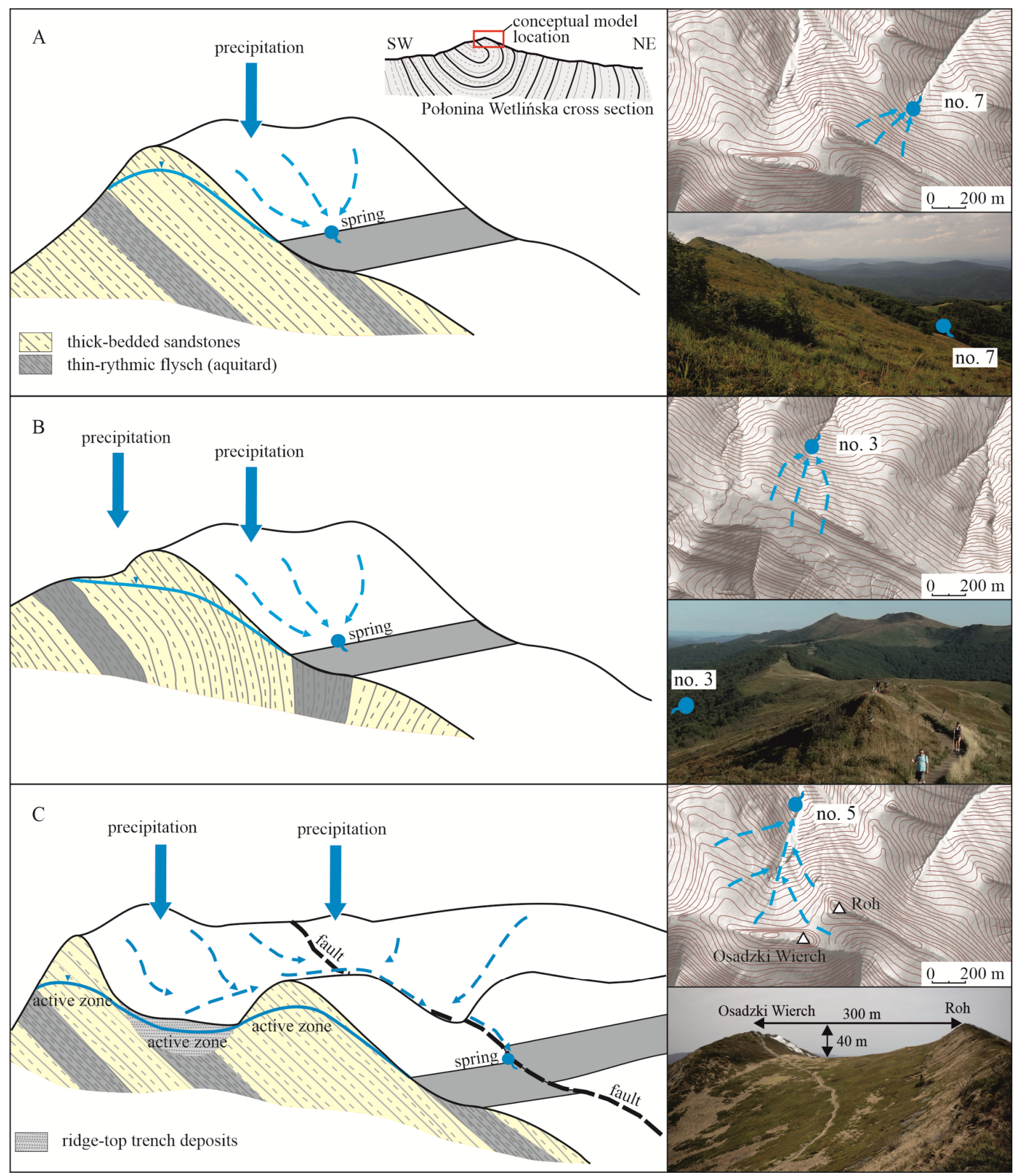

Fig. 6 Conceptual model of spring No. 7 (A) No. 3 (B) and No. 5 (C) recharge pattern (modified on Płaczkowska et al. 2018).

the snowmelt period (March and April, Fig. 2), onto which the current rainfall recharge is superimposed. This causes a quick response and an increase in spring discharge, which may indicates an increase in hydrostatic pressure in the water-bearing system. It is worth to underline that the longer response during spring months may be distorted by the timing of input of snowmelt. A rapid response of the groundwater table after the winter-spring recharge period was also observed in chalk aquifers of southern England. During this season, the unsaturated zone was the thinnest and the unsaturated zone moisture content was the highest (Lee et al. 2006). In karst systems, the variation in response rates and high correlation 
coefficients for different cumulative rainfall periods have been associated with antecedent moisture storage, thickness of the saturated zone, and the geometry of the spring catchment, which may be temporally or spatially varied (Fiorillo and Doglioni 2010). In the area studied for this project, the depletion of groundwater resources in the summer and autumn is balanced only partly with rainfall recharge and, therefore, the response of spring discharge to rainfall tends to be longer. This longer response time indicates an increase in the importance of overall rainfall in the few months preceding a given discharge and a decrease in the significance of the faster recharge component, i.e. shallow subsurface water. Then, due to limited groundwater resources, the importance of water releasing triggered by an increase in pressure is less visible. Water is gravitationally yielded from the less saturated aquifer - acting as unconfined in this case - and the observed increase of spring discharge is caused by the wave of new water migrating through the system rather than by an increase in pressure.

The dependence of SEC on spring discharge presented in the paper also confirms the existence of two flow systems. Furthermore, the results may be useful for identifying the drainage area of springs. The small SEC and water temperature range (Table 2, Table 3), accompanying the large range of discharge variability in springs No. 3 and 5, indicates a negligible inflow of fresh infiltration water. The increase in spring discharge is supposed to be primarily caused by an increase in pressure within aquifers in the period following rainfall events, which forces the releasing of water already present in the aquifer prior to recent recharge (in a manner similar to the typical piston flow model). The lack of a clear relationship between discharge and SEC is also confirmed by the model of recharging springs in the Połonina Wetlińska, with an upper, active part of the aquifer and lower passive zone, proposed by Płaczkowska et al. (2018). These springs' location close to the ridge line and the general low SEC indicate that the springs drain the fissure-pore system, which consists of the regolith (including soils, weathered rock, material displaced by mass movements) and the aquifer in thick-bedded Otryt sandstone (Fig. 6B, Fig. 6C). In the case of spring No. 7 (Fig. 6A), a clear decrease in SEC along with an increase in spring discharge suggest a simple pattern of water dilution in the shallow fissure-dominated aquifer with infiltrating rainwater, where pressure no longer plays a significant role in gravitational water migration (the "unconfined model" mentioned above). A one-off study on SEC and the discharge of 35 springs carried out in the dry period in the Połonina Wetlinska Massif showed no relationship between SEC and discharge, which are probably more dependent on the pattern of groundwater recharge and the size of the drainage area, which vary for each individual spring (Kisiel et al. 2018). Generally, the average SEC from measurements carried out in a number of hillslope springs in the Bieszczady Mountains is of ca. $160 \mu \mathrm{S} \cdot \mathrm{cm}^{-1}$ (Rzonca et al. 2008; Kisiel et al. 2018), which constitutes a much lower value (up to several times) than for many springs documented in the western part of the Flysch Carpathians (Lasek 2008; Krause et al. 2015). An area similar to the Połonina Wetlińska seems to be the Babia Góra Massif, located about $200 \mathrm{~km}$ west of the Flysch Carpathians range, where the ridge zone built of Magura sandstone is characterized by spring water with SEC in the range of 38-225 $\mu \mathrm{S} \cdot \mathrm{cm}^{-1}$ (Malata 2015; Łajczak 2016).

The discharge of the studied springs, the storage capacity of the aquifers that feed them, the response to rainfall, the fissure-pore system of groundwater flow, and the variation of SEC clearly indicate the spatial complexity of the drainage area, which definitely cannot be limited to the topographic catchment areas for these springs. In aquifers recharging such springs, shallow groundwater migrates primarily through a network of joints and faults, which are the result of tectonic activity, gravitational processes, and weathering (Kleczkowski 1979; Gutiérrez et al. 2012; Diodato et al. 2014; Placzkowska et al. 2018). The drainage from a more distant area in a fissure-pore aquifer is possible owing to the steep dip of the rock layers in the NE direction, which facilitates the flow of water from the southern slope of the Połonina Wetlińska ridge to its northern slope - where the studied springs are located (Fig. 6B, Fig. 6C). Another possibility is the groundwater flow referring to the strike of rock layers consistent with the ridge orientation, as well as the use of local structural discontinuities. The differences in the size of the recharge area of the studied springs may also be related to the altitude of their occurrence, i.e. springs with a longer response time to rainfall recharging from a fissure-pore aquifer are located at a lower altitude of about $950 \mathrm{~m}$ a.s.l. (No. 3 and 5), while 
spring No. 7, reacting to rainfall faster mainly through fissure flow, is located at an altitude of 1,079 m a.s.l. The asymmetry consisting in a significantly higher spring discharge on the northern slope of the Połonina Wetlińska (Mocior et al. 2015) is also visible in the river runoff in the small catchments around the Massif, i.e. during low flow periods the river runoff was even several times higher in the catchments on the northern side of the Połonina Wetlińska (Mostowik et al. 2019a).

It is worth paying attention to the role that the structures of ridge-top trenches (sackungen) can play in water storage. Above spring No. 5, on the top of the Połonina Wetlińska, between two parallel ridges, there is a trench with a maximum width of up to 300 $\mathrm{m}$ and a depth of up to $40 \mathrm{~m}$ (Fig. 6C). Owing to their morphology and filling by sediments less compact than the surrounding parent rocks, ridge-top trenches induce local reduction of surface flow and an increase in infiltration and groundwater storage. In extremely wet periods, this increase may contribute to the destabilization of neighbouring slopes and to the activation of mass movements, such as landslides (Johnson and Cotton 2005; Gutiérrez et al. 2012). Geomorphological mapping conducted in the Połonina Wetlińska Massif showed that mass movements had already occurred in this area, i.e. two landslides created by lateral spreading and rock flow, reaching the ridge of the Połonina, were mapped on the slope above spring No. 5 (Strzyżowski 2015). In another part of the Flysch Carpathians with a similar monoclinic massif structure (Moravskoslezské Beskydy, Czechia), Břežný et al. (2018) showed that such a dip of rock layers facilitates gravitational slope deformations. Additional factors such as recharging groundwater resources by infiltration in the ridge-top trench and in thick landslide material cause perennial discharge in the spring No. 5, which is the highest among the over 800 springs mapped in the Polonina Wetlińska Massif.

\section{Conclusions}

The research provided an insight into a complex system of recharge and flow patterns in flysch aquifers feeding springs located in the upper part of a slope, close to a ridge line. According to the presented evidence, the groundwater flow pattern of the studied springs may be described by a model consisting of two crucial systems: 1) a relatively deep, fissure-pore flow system with a long response time to precipitation and 2) a shallow, fissure-dominated system with a short response time to precipitation, which is superimposed on the longer response. It is a novelty, that cumulative rainfall over a period ranging from several days to $1-3$ months has the highest correlation with discharge in the Outer Carpathians. In consequence, fissuredominated systems, as characterized by a short response and a limited recharge area, pretend to be very sensitive component of headwater catchments, particularly due to on-going changes in precipitation supply.

It is worth to underline, that faster response to rainfall occurs at the beginning of the warm half-year, when aquifers and slope deposits are saturated after snowmelt, while in the summer and autumn months the response time increases. The differences in recharge patterns between springs were also confirmed in studies of the specific electrical conductivity of water. A small range of SEC together with the varying discharge of springs No. 3 and 5 indicate a minor role of direct infiltration fluxes. Therefore, in the fissure-pore systems with an extended recharge area, the pressure which causes release of older water with an averaged ion concentration is supposed to play a significant role and the deep flow system is here dominant. In turn, in the pattern of drainage represented by spring No. 7, a key role is played by shallow subsurface water migrating mainly through fissures and characterized by low mineralization. However, it should be emphasized that the interpretation of the results is to some extent limited due to lack of full knowledge about precipitation totals in the ridge area and the spring's discharge response disturbances during snowmelt period.

It would appear that the differences in spring response to rainfall across such a small area as the Połonina Wetlińska Massif are determined by the local bedrock and regolith structures, which role has been underestimated thus far. Firstly, the occurrence of joints and faults of different origin promotes the enlargement of groundwater storage capacity, which is higher than in many other flysch areas of the Carpathians. Secondly, the monoclinal steep dip of rock layers facilitates the extension of the drainage area due to an inflow of infiltrating water from the opposite site of the ridge. Thirdly, gravitational slope deformations modify the conditions of subsurface water flow on the 
slope and may locally increase the retention capacity and the thickness of the active zone, with a particular increase in infiltration in the area of occurrence of ridge-top trenches. Further studies of spring water isotopes and of subsurface structures, discontinuities,

\section{Acknowledgement}

This research was supported by the National Science Centre of Poland, as a part of the research project (grant number 2016/23/N/ST10/01327).

Open Access This article is distributed under the terms of the Creative Commons Attribution 4.0 International License (http://creativecommons.

\section{References}

Bartnik A, Moniewski P (2019) Multiannual variability of spring discharge in southern Poland. Episodes 42(3): 187-198. https://doi.org/10.18814/epiiugs/2019/019015

Bonacci O (1987) Karst hydrology with special reference to the Dinaric Karst. Springer Series Phys Environ 2: 1-184.

https://doi.org/10.1007/978-3-642-83165-2

Břežný M, Pánek T, Lenart $J$, et al. (2018) Sackung and enigmatic mass movement folds on a structurally-controlled mountain ridge. Geomorpholology 322: 175-187.

https://doi.org/10.1016/j.geomorph.2018.09.004

Buczyński S, Rzonca B (2011) Effects of crystalline massif tectonics on groundwater origin and catchment size of a large spring area in Zieleniec, Sudety Mountains, southwestern Poland. Hydrogeol J 19: 1085-1101.

https://doi.org/10.1007/s10040-011-0732-3

Buczyński S, Olichwer T, Tarka R, et al. (2007) Water bearing of Carpathian flysch formation base on springs research in Krynicki Beskid - Tylicz region. Współczesne problemy hydrogeologii 13(2): 403-411. (In Polish)

Chelmicki W, Jokiel P, Michalczyk Z, et al. (2011) Distribution, discharge and regional characteristics of springs in Poland. Episodes 34(4): 244-256.

https://doi.org/10.18814/epiiugs/2011/v34i4/oo

Chowaniec J, Oszczypko N, Witek K (1983) The hydrogeological characteristics of the Krosno beds on the Central Carpathian Depression. Kwartalnik Geologiczny 27: 797-810. (In Polish)

Diodato N, Guerriero L, Fiorillo F, et al. (2014) Predicting monthly spring discharges using a simple statistical model. Water Resour Manag 28: 969-978.

https://doi.org/10.1007/s11269-014-0527-0

Dobek M (2007) The reaction of groundwater levels to the rainfall in the years 1961-1981 in selected areas of the Lublin Upland. Annales UMCS Sectio E 62: 49-55. (In Polish)

Fiorillo F, Doglioni A (2010) The relation between karst spring discharge and rainfall by cross-correlation analysis (Campania, southern Italy). Hydrogeol J 18(8): 1881-1895. https://doi.org/10.1007/s10040-010-0666-1

Fiorillo F, Esposito L, Guadagno FM (2007) Analyses and forecast of water resources in an ultra-centenarian spring discharge series from Serino (Southern Italy). J Hydrol 336: 125-138.

https://doi.org/10.1016/j.jhydrol.2006.12.016

Gutiérrez F, Linares R, Roqué C, et al. (2012) Investigating gravitational grabens related to lateral spreading and evaporite dissolution subsidence by means of detailed and depth of deformed zones using geophysical techniques (e.g. electrical resistivity tomography) can undoubtedly contribute to a more detailed characterization of recharge and flow patterns.

org/licenses/by/4.o/), which permits unrestricted use, distribution, and reproduction in any medium, provided you give appropriate credit to the original author(s) and the source, provide a link to the Creative Commons license, and indicate if changes were made. mapping, trenching, and electrical resistivity tomography (Spanish Pyrenees). Litosphere 4(4): 331-353. https://doi.org/10.1130/L202.1

Haczewski G, Kukulak J, Bąk K (2007) Geology and Relief of the Bieszczady National Park. Kraków: Wydawnictwo Naukowe AP. p 155. (In Polish)

Halihan T, Wicks CM (1998) Modeling of storm responses in conduit flow aquifers with reservoirs. J Hydrol 208(1-2): 8291.

https://doi.org/10.1016/Soo22-1694(98)oo149-8

Humnicki W (2013) Reaction of selected springs in the Pieniny Mts. for thawing recharge. Biuletyn PIG 456: 205-210. (In Polish)

Jemcov I (2007) Water supply potential and optimal exploitation capacity of karst aquifer systems. Environ Geol 51: 767-773.

https://doi.org/10.1007/s00254-006-0389-8

Johnson PL, Cotton WR (2005) The Santiago landslide and associated ridge-top graben (sackungen): implications for paleoseismic landslide studies. Environ Eng Geosci 11(1): 5-15. https://doi.org/10.2113/11.1.5

Kacprzak A (2001) Relations between Soil Properties and Slope Covers in the Bieszczady Mts. PhD thesis, Jagiellonian University, Kraków. p 129. (In Polish)

Kisiel M, Bochnak D, Jastrzębska B, et al. (2018) Chemical composition of spring water in the Polonina Wetlinska massif. Roczniki Bieszczadzkie 26: 205-222. (In Polish)

Kisiel M, Dojtrowska I, Kucała M, et al. (2015) Temperature of spring water in Połonina Wetlińska massif. Roczniki Bieszczadzkie 23: 225-237. (In Polish)

Kleczkowski AS (1979) Hydrogeological Conditions of the Territories surrounding Poland. Warszawa: Wydawnictwo Geologiczne. p 184. (In Polish)

Kovács A, Perrochet P (2008) A quantitative approach to spring hydrograph decomposition. J Hydrol 352: 16-29. https://doi.org/10.1016/j.jhydrol.2007.12.009

Kovács A, Perrochet P, Király et al. (2005) A quantitative method for the characterisation of karst aquifers based on spring hydrograph analysis. J Hydrol 303(1-4): 152-164. https://doi.org/10.1016/j.jhydrol.2004.08.023

Krause R, Smieja A, Smieja-Król B, et al. (2015) Springs with calcareous tufa in the valley of the Jamne Creek in Gorce. Ecol Eng 41: 36-45.

https://doi.org/10.12912/23920629/1827 (In Polish)

Kukulak J (2001) Variability of type and structure of the regolith 
in the Bieszczady Mountains (Ustrzyki Górne). In: Klimek K et al. (eds.), The Regolith as Record of Climate Changes in the late Vistulian Glaciation and Holocene. Wydawnictwo Uniwersytetu Śląskiego, Sosnowiec. pp 23-27. (in Polish)

Lasek J (2008) Chemistry of groundwater outlflows in the Ryjak stream catchment, Magurski National Park. In: Partyka J et al. (eds.), Waters in Protected Areas. Wydawnictwo IGiGP UJ, Kraków. pp 201-211. (In Polish)

Laszczak E, Ziółkowski L, Siwek J (2011) Precipitation and snow cover. In: Rzonca B et al. (eds.), Hydrology of Bieszczady Mts. Catchments of San and Solinka up to Lake Solina. Wydawnictwo IGiGP UJ, Kraków. pp 21-29. (In Polish)

Lee JY, Lee KK (2000) Use of hydrologic time series data for identification of recharge mechanism in a fractured bedrock aquifer system. J Hydrol 229(3-4): 190-201. https://doi.org/10.1016/Soo22-1694(00)00158-X

Lee LJE, Lawrence DSL, Price M (2006) Analysis of water-level response to rainfall and implications for recharge pathways in the Chalk aquifer, SE England. J Hydrol 330: 604-620. https://doi.org/10.1016/j.jhydrol.2006.04.025

Leszkiewicz J, Różkowski J (2000) Response of karstfissure springs to infiltration recharge in the area of Ojców National Park (Cracow Upland, southern Poland). Kras i Speleologia 10: 27-44.

Łajczak A (1996) Hydrology. In: Skiba S (eds.), Bieszczady National Park Protection Plan. Description of the Abiotic Environment and Soils. Bieszczadzki Park Narodowy, Ustrzyki Dolne. pp 12-38. (In Polish)

Łajczak A (2016) Waters of Mount Babia Góra. Zawoja: Wyd. Babiogórskiego Parku Narodowego. p 423. (In Polish)

Machowski G (2010) Reservoir Parameters of Microporous and Fractured Krosno Sandstone in Oil- and Gas-bearing Zone of the Central Carpathian Depression. PhD thesis, UST, Kraków p. 189. (In Polish)

Maillet E (1905) Underground and Fluvial Hydraulics Tests. Paris: Librairie Scientifique, Hermann, p. 218. (In French)

Malata M (2015) Seasonal physico-chemical changes of water springs in the Babiogórski National Park. Sci Rev Eng Environ Sci 67: 26-39. (In Polish)

Malata T, Jankowski L, Żytko K (2006) Detailed Geological Map of Poland 1:50000, Lutowiska Sheet. Warszwa: Wydawnictwo PIG-PIB. (In Polish)

Maloszewski P (2004) Mean residence time (ages) in subsurface water. In: Xi RZ et al. (eds.), Research Basins and Hydrological Planning. AA Balkema Publishers, London. pp 47-51.

Maloszewski P, Stichler W, Zuber A (2004) Interpretation of environmental tracers in groundwater systems with stagnant water zones. Isot Environ Healt S 40(1): 21-33 https://doi.org/10.1080/10256010310001645717

Maloszewski P, Stichler W, Zuber A, et al. (2002) Identifying the flow systems in a karstic-fissured-porous aquifer, the Schneealpe, Austria, by modelling of environmental ${ }^{18} \mathrm{O}$ and $3 \mathrm{H}$ isotopes. J Hydrol 256: 48-59. https://doi.org/10.1016/So022-1694(01)00526-1

Mocior E, Rzonca B, Siwek J, et al. (2015) Determinants of the distribution of springs in the upper part of flysch ridge in the Bieszczady Mountains in southeastern Poland. Episodes 38(1): 21-30.

https://doi.org/10.18814/epiiugs/2015/v38i1/oo3

Mostowik K, Górnik M, Jaśkowiec B, et al. (2016) High discharge springs in the Outer Flysch Carpathians on the example of the High Bieszczady Mountains (Poland). Carpath J Earth Environ Sci 11(2): 395-404.

Mostowik K, Jastrzębska B, Kowalik K, et al. (2019a) Groundwater runoff in elementary catchments in the Bieszczady Mountains. Roczniki Bieszczadzkie 27: 367-387. (In Polish)

Mostowik K, Kisiel M, Siwek J, et al. (2018) The storage capacity of groundwater reservoirs in the High Bieszczady Mountains, SE Poland. Przegląd Geograficzny 90(1): 93-110. https://doi.org/10.7163/PrzG.2018.1.5. (In Polish)

Mostowik K, Siwek J, Kisiel M, et al. (2019b) Runoff trends in a changing climate in the Eastern Carpathians (Bieszczady Mountains, Poland). Catena 182. https://doi.org/10.1016/j.catena.2019.104174

Negi GCS, Joshi V (2004) Rainfall and spring discharge patterns in two small drainage catchments in the Western Himalayan Mountains, India. The Environmentalist 24(1): 1928.

https://doi.org/10.1023/B:ENVR.ooooo46343.45118.78

Padilla A, Pulido-Bosch A (1995) Study of hydrographs of karstic aquifers by means of correlation and cross-spectral analysis. J Hydrol 168(1): 73-89.

https://doi.org/10.1016/0022-1694(94)02648-U

Pińskwar I, Choryński A, Graczyk D, et al. (2019) Observed changes in extreme precipitation in Poland: 1991-2015 versus 1961-1990. Theor Appl Climatol 135(1-2): 773-787. https://doi.org/101007/s00704-018-2372-1

Płaczkowska E, Górnik M, Mocior E, et al. (2015) Spatial distribution of channel heads in the Polish Flysch Carpathians. Catena 127: 240-249.

https://doi.org/10.1016/j.catena.2014.12.033

Płaczkowska E, Siwek J, Maciejczyk K, et al. (2018) Groundwater capacity of a flysch-type aquifer feeding springs in the Outer Eastern Carpathians (Poland). Hydrol Resour 49(6): 1946-1959. https://doi.org/10.2166/nh.2018.200

Rzonca B, Kołodziej A, Laszczak E, et al. (2008) Springs of the upper Wołosatka River catchment in the Wysokie Bieszczady Mountains. Przegląd Geologiczny 56(8/2): 772-779. (In Polish)

Strzyżowski D (2015) Factors controlling the relief development of Połonina Wetlińska and Połonina Caryńska. Roczniki Bieszczadzkie 23: 251-264. (In Polish)

Szwed M (2019) Variability of precipitation in Poland under climate change. Theor Appl Climatol 135(3-4): 1003-1015. https://doi.org/10.1007/s00704-018-2408-6

Szwed M, Pińskwar I, Kundzewicz ZW, et al. (2017) Changes of snow cover in Poland. Acta Geophys 65: 56-76. https://doi.org/10.1007/s11600-017-0007-z

Sukhija BS, Reddy DV, Nagabhushanam P, et al. (2003) Recharge processes: piston flow vs preferential flow in semiarid aquifers of India. Hydrogeol J 11: 387-395. https://doi.org/10.1007/s10040-002-0243-3

Zhang Z, Chen X, Chen X, et al. (2013) Quantifying time lag of epikarst-spring hydrograph response to rainfall using correlation and spectral analyses. Hydrogeol J 21: 1619-1631. https://doi.org/10.1007/s10040-013-1041-9

Zuber A, Małecki JJ, Duliński M (2008) Groundwater ages and altitudes of recharge areas in the Polish Tatra Mts. as determined from ${ }^{3} \mathrm{H}, \delta^{18} \mathrm{O}$ and $\delta^{2} \mathrm{H}$ data. Geol Q 52(1): 71-80. 